\title{
Principles and Methods on Trademark Translation
}

\author{
YAN Yi-bo \\ Heze University, Heze, China
}

\begin{abstract}
It is obvious that trademark is closely connected with commodity, so it plays an important role in pushing the development of international market and creating wealth for the enterprise. This paper first introduces the framework of trademark translation, and then presents some problems in the process of trademark translation. In the end, from a practical angle it discusses the applicable methods of trademark translation. Meanwhile, the principles that translators should follow in trademark translation are put forward to help them to achieve the expected goal of the trademark translation.
\end{abstract}

Keywords: trademark translation, translation principles, existing problems, translation methods

\section{Introduction}

Trademark is another image for products; it represents the image of goods and frequently appears in the import and export trade markets today, so a good trademark translation of commodity is very important. On one hand, goods will be sold to different regions and it is obvious that translators will face cultural differences. On the other hand, cultural differences are connected with different languages and we can produce various trademarks. So it is necessary to study the trademark translation, and translator's research about trademark translation is also very urgent.

In order to further understand the meaning of trademark, the crucial step for translators is to understand its connotation. Only translators deeply understand the trademark's connotation, and then they could create a unique trademark for the product. In fact, trademark is any visible sign or device used by a business enterprise to identify its goods and distinguish them from those made or carried by others. Trademark in its formation can be words or group of words, letters, digital symbols, external factors, the shape, or other elements of products or their packages. Therefore, the trademark not only represents their products but also the image of the entire enterprise, and it is different from other similar products. Successful brands are not only making great wealth for the companies but also gaining more places for products in the international market. Trademark translation means not only understand the essence but also the existing problems; trademark translation also involves the translation principles and what methods should be taken, so translators should fully consider the different factors in the process of translation. Translators should know that the uniqueness of the trademark translation can present products' characteristics, and conform to the intrinsic need of consumers. Only in this way will the translator see the effect he wants. This paper is divided into five parts: The first part is connected with the simple introduction of trademark translation; the second part is the overview of the trademark; the third part is problems in trademark translation; the fourth part is the principles about trademark translation; the last part is the methods applied in trademark translation.

YAN Yi-bo, lecturer, M.A., Foreign Language Department, Heze University. 


\section{Overview of the Trademark}

Trademark translation is a process of encoding and restructuring and further processing. It is certain that a unique trademark translation contributes to huge wealth for business, whereas an improper trademark may cause great loss and bring unpredictable consequences. Therefore, an enterprise's future is closely linked with trademark translation.

\section{Definition of the Trademark}

Oxford Advanced Learner's English-Chinese Dictionary defined trademark as "name, trademark symbol and design once used by a company, other companies are not allowed, or entitled to use" (Hornby, 1948).

The definition of the trademark is determined by the WTO (World Trade Organization). In this article, people could know from the deeper level of trademark:

Any sign, or any combination of signs, can distinguish one trademark from another, it is sure that the influence brought by the trademark itself. Usually in the situations of market transaction, trademark includes some factors: letters, words, sounds, symbols, etc., those factors put together and make definite relation between each other. Trademark is an important part of trademark propaganda that can be vocalized. (LIU, 2003, pp. 68-71)

The particularity of trademark decides the particularity of goods and it only appears in the commodity sales; this particularity can let customers distinguish this product and other similar products which are made by other companies.

\section{The Classification of the Trademark}

There are many kinds of methods about trademark classification. Based on reputation, it can be divided into ordinary trademark and influential trademark, and the second trademark is a successful trademark which everyone knows it. The difference is that the former cannot be protected by special laws while the second does. How does a trademark form? In fact, it can be divided into word trademark and trademark composed of design, and translators call the second one logo. This article will connect the rich vocabulary with different trademarks in the process of trademark translation and set up a bridge between the form of English and Chinese trademark translation.

\section{Problems in Trademark Translation}

As more and more foreign products are pouring into China and Chinese products are exporting to abroad as well, trademark has become a necessary part of the marketing strategy. An appropriate trademark can win a large number of customers and stimulate their purchase desire, while an appropriate trademark translation will also bring negative effects to the image of the product. Translators should not only analyze these problems but also listen to various suggestions. The following thesis will show us the problems in trademark translation.

\section{Problems Existing in the Chinese-English Trademark Translation}

China is a multi-ethnic country with rich culture and traditions, so translators should concern cultural custom and historical background when they translate trademarks and then many consumers will accept the products (KONG, 2005, pp. 9-10). Many of Chinese manufacturers completely ignore the importance of trademark translation. Some translation of trademarks reflects the irresponsibility and negligence of the translators, and customers can find their recklessness at the end of tasks. They are not aware that such attitude may lose a lot of potential customers, because they do not look at problems from a long term view. 


\section{Improper Translation}

Sometimes trademarks' translation from Chinese into English will not bring the market, while improper translation will produce certain negative effects on products. So the improper translation is a significant factor to make bad effects for products.

There is a story telling about trademark translation in Yangtze Evening Post which gives us an example, “卡卡” is a kind of biscuits that are made in China. The translator uses four letters to translate it as "KAKA". When Chinese sells "KAKA" in Russia, the native Russian could not believe that all the packages printed with "KAKA", because in the mind of the Russians, "KAKA" represents "shit". "金鸡-alarm clock" sells very well in the Chinese market and has many fans in China. Its foreign version is "Golden Cock". When foreigners see this kind of translation, they first feel very funny, because cock represents a vulgar meaning and sometimes it is to be seen as slang in the West. So there are few people who want to buy this kind of clock. If translators used the word "Rooster", it would make a better image. Because customers love the image of "Rooster"; sometimes this kind of clock could be treated as rooster to wake you up every day.

Sometimes, some trademarks' literal meaning can make us deeply understand the connotation of the goods, but translators cannot use this method for all trademarks, because some trademark translation is too complicated, or sounds can let a person produce bad associations. For example, the battery brand “白象” was translated into "White Elephant" at first, and it did not sell well in Western countries, because "White Elephant" means "money-consuming".

\section{Problems Existing in the English-Chinese Trademark Translation}

According to a theory about English-Chinese translation of practical course (HE, 2006, p. 202); it is really free to translate trademarks from Chinese into English; it is more flexible and easier to translate trademarks from English to Chinese. For example, “可口可乐” (coca cola), is the model of trademark translation. However, there are also some problems in the process of using this method.

\section{Lack of Enduring Appeal}

The English-Chinese trademark translation will bring customers a kind of foreign style. When brand names appear in people's field of view at the first time, it might seize the curiosity of consumers quickly. Because the English-Chinese trademark translation is not only fascinating, but also associates with foreign style. However, because many similar brand names have appeared in China, Chinese consumers are gradually losing interest of the products. Now there are much similar trademarks” translation, like “真维斯”, “阿迪达斯”, “星巴 克”, and “别克” are words full of Chinese characteristics as “斯” and “克”.

\section{Lack of Consistency}

It is certain that every country has its own custom; the way which translator would apply is very different, too. For example, "Head and Shoulder's" is a kind of cream shampoo and translated as “海伦仙度斯” in Taiwan, but it was not easy to understand the essence of products when they first heard this name; while this shampoo is translated as “海飞丝” in mainland and customers could know the purpose of this product through its trademark. Different translation versions will cause confusion to consumers. Because they cannot sure that they buy the real product. This will give manufacturers certain negative impacts.

\section{Suggested Revolutions}

Trademark translation always causes some problems, and it is very difficult for translators to satisfy the 
brand names; the main cause of these problems is that the translator and the manufacturer do not put the interests of customers first. "A trademark has an existence separated from an actual product or service: It has a life of its own" (Randall, 1997). The essences of the trademark itself affect the sales and price of products. So translators should not only be serious with the "accuracy" but also conform to the "aesthetics" and other important factors of products. Manufacturers should make an internationalization road for their products at the same time.

\section{Principles of Trademark Translation}

The translator need learn to obey principles; it mainly depends on professional level for translators, especially their creativity. Duo to the environment, history, economy, religion, and other factors, people's way of thinking, concepts, and all these differences influence what kind of principle we should adopt.

\section{Conforming to the Product Characters}

Characteristics of goods not only refer to products' material; characteristics also mean different functions. Therefore, translators should recognize the characteristics of products before they give it trademarks. In order to make clients to have a broader knowledge of the product and let them quickly learn characteristics and advantages through the mark of trademark. For example, the makeup "Etude House" is made for young girls, and it is translated as “爱丽小屋或伊蒂之屋”; it provides for young girls who begin to learn how to make up.

\section{Conforming to the Conciseness of Trademark}

If the translator wants consumers to have deep impression on their products, the first thing they should do is to seize the curious psychology of consumers, and create a clear but unique trademark. A good trademark pronunciation should have rhyme and make people easy to remember, and the word connotation is so rich that it can produce a better association (HE, 1997, pp. 30-36). Like trademark “Skin Food (思亲肤)", wins a lot of young girls' love because this kind of product can satisfy the demand of their hearts. Another trademark "VOV" translated into “薇欧薇”. It is equal with the character of conciseness. All of those trademarks translation above show us the feature of conciseness. The sort of trademarks not only contains the beauty but also seizes the customers' requirements.

\section{Conforming to the International Standards}

The concept of "Nationality" is set up by PAN Gong at the first time. "Trademark translation not only should respect the national psychology, seize the associative meaning of words, but also familiar with the national conditions and national features" PAN Gong (1996, pp. 26-27) said. CHEN Zhen-dong (2005, pp. 52-54) suggests that trademark translation need know national culture difference at first, such as moral quality, value guidance, and religious theories, etc. While XU Hui (2004, pp. 55-56) believes that the trademark translation should convey characteristic information of national culture to consumers. For example, the Shandong "Qinqi” produces "Qinqi" motorcycle. "Qinqi” is not translated into English directly, so as to avoid doubt on the quality of products, but used Chinese pinyin from "Qinqi"; it uses Latin alphabet rather than Chinese pronunciation. Compared with “Lux (力士)” and “Blue Bird (蓝鸟)”, it registers easily overseas.

\section{Conforming to the Indigenization}

It is easier for people to buy local products, but they find it hard to accept foreign products. The concept about indigenization means we should correctly treat difference among various cultures and make our trademark translation have more local features. Culture could shape the form of two languages (JIN, 2005, p. 
91). People can see that the translation of two cultures. With the sustainable development of the economic globalization, businessman must realize the different cultural traditions and customs that are involved in global economy; only in this way could trademarks correspond with the original connotation of products. For example, there is a kind of condiment translated into "Tabasco" and its place of origin is Tabasco (墨西哥东南部的州塔 巴斯科). The brand “波尔多葡萄酒” is translated into “Bordeaux Wines”, and it connects with producing area “Bordeaux (波尔多)”; “Bordeaux (波尔多)” is the place that is famous for making wine. We can also find a lot of trademarks with the characteristics of indigenization.

Trademark connects with culture, and sometimes reflects culture, and it is also constrained by the culture. Just as Robert Lado (1957) said: "We changing life experience into language, and giving meaning to the language, is the reason why be affected by cultural restrictions, while language is different because of the culture difference" (p. 11). Therefore, translators must study the potential cultures to prevent the language taboos' appearance.

\section{Conforming to the Aesthetic Dimension}

The trademark translation cannot let consumers have a bad experience; this requires the translator to consider the culture and the historical perspective fully. For example, the well-known trademark "Charmzone" is translated into “婵真”; Chinese have china (瓷器) while European have "Meissen (麦森)". "Meissen" is a kind of "German porcelain brand" with three thousand years of history, and it is famous for elegance and royal temperament. It is the model of aesthetic paradigm. So the translators need to avoid touching the taboo of consumers in the translation of trademark.

\section{Methods Applied in Trademark Translation}

Trademark means business. Trademark concerns image, reputation, and actual quality, etc., a series of important factors of enterprises. When the translators design the trademark for products and manufactories, they just use up all the brain cells to create a unique trademark for gaining places in the international competition; a unique trademark can make tremendous profits. Of course, trademark translation sometimes need not cost so many efforts, but we should choose methods seriously.

\section{Using Pinyin}

Chinese pinyin is made up of letters and sounds with meaning of words. It is commonly used for Chinese trademark translation. For example, the air-conditioner Chunlan (春兰空调), the coffee Lishen (力神咖啡), etc. Some companies use the Chinese pinyin to represent trademarks: Tian Da (天达), Changhong (长虹), and Luxixi (鲁西西). When translators adopt the method of Chinese pinyin to translate trademarks; they should pay attention to establish contact with the original name. There is a trademark translated as " ${ }^{*} \mathrm{U}^{*} \mathrm{C} * \mathrm{~K}$ " and it is a kind of pliers. May be it is the abbreviation of company's name. But "fuck" is a bad English word. Its meaning is "fraud" and "deceiver", and even means sex in slang. Therefore, the translator is not satisfied with the method of using pinyin, and this method is difficult to reach a certain standard.

\section{Paraphrasing}

Translators like to associate trademarks with real life, because they think such products can be more close to daily life. For example, the trademark of renowned company “爱茉莉太平洋集团” is “Amore Pacific”; the clothing brand “Basic House” is translated into “百家好”; the toy “小熊维尼” is translated into “Teenie Weenie"; the detergent “Mr. Muscle” translated as “威猛先生”, and the translator sets up a connection between 
brave and fierce, the shampoo "Feather" is translated into "飞逸", and it gives a person a kind of feeling of hair with high quality; another Italy fashion trademark "Miss Sixty" is famous for sexy jeans, and it will make us think of attractive curve of women. Sometimes it is difficult to make a definite name for products; translators need to keep thinking until they find a satisfactory conclusion. The trademark “双星” is translated into "Double Star"; Beer Company in Guangzhou has another English trademark "Guang's". All these goods visually show their own characteristics.

\section{Using Transliteration}

Transliteration refers to writing or interpreting a letter or a word using the closest corresponding letters of a different alphabet or language. It is a very practical translation method. For example, the trademark "Aiwa" is translated into “爱华”; The trademark “Casio" is translated into “卡西欧”; Sometimes the translator needs to use the method of transliteration correctly. We all know that a trademark, associated with some names in our life, places, beautiful spots, and those things with international characteristics. For example, "Nokia" (诺基亚) is named by a small town Nokia in the south of Finland. Sometimes, transliteration shows the characteristics of the product directly, or it is easy to find examples, for example, “奔腾” (the Internet Pentium) means fast running speed; B \& Q (安居乐业) means people to live and work in peace and contentment. “海信电器公司” is translated into “Hisense”, and car brand “Cadil-Lac” is translated into “卡迪拉克”.

\section{Conclusion}

This paper depicts a framework of the trademark translation and shows some existing problems. Translators will face certain difficulty in the process of translation, so they can follow the methods and principles above. This paper could bring enlightenment for translators and they can make good use of it. The translator only realizes qualities, values, connotations, and features of the products, and then they can use their own ability to create great trademarks.

\section{References}

CHEN, Z. D. (2005). Analysis on trademark translation. Shanghai Journal of Translators, 2, 52-54.

HE, S. N. (2006). A practical course in English-Chinese translation. Nanjing: Southeast University Press.

Hornby, A. S. (1948). Oxford advanced learner's English-Chinese dictionary. London: Oxford University Press.

JIN, M. L. (2005). Sociolinguistics \& English learning. Tianjin: Nankai University Press.

KONG, L. C. (2005). The combination of Chinese and Western trademark translation. Seeker, 10, 9-10.

Lado, R. (1957). Linguistics across culture. Michigan: University of Michigan Press.

LIU, F. G. (2003). Several important issues on Chinese-English trademark translation. Chinese Translators, 6, 68-71.

Ogilvy, D. (1960). Oglivy on advertising. London: Oxford University Press.

PAN, H. (1996). The requirement of trademark translation.Chinese Translators, 6, 26-27.

Randall, G. (1997). Creating community: Finding meaning in the place we live. London: Oxford University Press.

XU, H. (2004). The interaction of trademark translation and cross-cultural differences. Shanghai Journal of Translators for Science and Technology, 3, 55-56. 